\title{
Rock mass characterization of rock ledge in powerhouse cavern at Shongtong Karcham Project, Himachal Pradesh
}

\author{
Prashant T Ilamkar and Shyam Sundar Singh \\ Geological Survey of India \\ Chandigarh, India \\ ptilamkar@gmail.com
}

\begin{abstract}
All the surface as well as underground hydropower stations has Electrical Overhead Travelling (EOT) cranes to facilitate erection and maintenance of the generating equipment. In the powerhouses built over ground, such cranes run on column and beam frames, provided for supporting the roof structure. However, in the case of underground powerhouses, built in rock caverns, advantage can be taken by utilizing the in situ rock walls to support the crane rails. This not only saves the construction of separate column and beam facility, but also allows early erection of the crane. The most commonly used methods for supporting the crane rails in underground powerhouses are building rock bolted, reinforced concrete beams along the powerhouse long walls or by providing a bench/rock ledge of suitable width along the walls. Bench/rock ledge type of design has been adopted in the under construction Shongtong Karcham HEP, Rekong Peo, District Kinnaur, Himachal Pradesh which is a run off the river scheme for harnessing hydropower potential of Satluj River between Powari and Ralli villages located in Kinnaur District of Himachal Pradesh. The barrage site is located $1.5 \mathrm{~km}$ upstream of the confluence of Tangling Khad with Satluj River near Powari village. The diverted water shall be conveyed through underground desilting chambers, $10.5 \mathrm{~m}$ finished dia Head Race Tunnel for a distance of $8095.39 \mathrm{~m}$ long, 33-meter dia. underground surge shaft and underground power house, to generate $450 \mathrm{MW}(3 \times 150 \mathrm{MW})$ of hydro power and to let out the TRT in the $d / s$ at Ralli. The Project components are mostly placed in underground and are located on the left bank of the Satluj River. The Project envisages construction of $\pm \mathbf{2 4 m}$ high diversion barrage across Satluj River to generate $450 \mathrm{MW}$ ( $3 \times 150 \mathrm{MW})$ of hydro power by utilizing a design head of $128 \mathrm{~m}$. The subsurface power house $(131.15 \mathrm{~m}(\mathrm{~L})$ ) $23 \mathrm{~m}(\mathrm{~W}) \times$ $44.29 \mathrm{~m}(\mathrm{H})$ has been excavated in $\mathrm{N}^{\circ}{ }^{\circ} \mathrm{E}$ direction parallel to the principal stress axis. The detailed geological mapping of the rock ledge in the power house cavern where Electrical Overhead Travelling (EOT) cranes is to be placed, was carried out on 1:100 scale. The $3 \mathrm{~m}$ height vertical wall of the rock ledge from base $\mathrm{El} . \pm 1827 \mathrm{~m}$ to top $\mathrm{EI} \pm 1830 \mathrm{~m}$ has been excavated in $\mathrm{N} 3^{\circ} \mathrm{E}$ direction from $\mathrm{RD} 40 \mathrm{~m}$ to $\mathrm{RD} 131.15 \mathrm{~m}$ and is driven across the foliation plane. During the geological wall mapping, it was found that the rock type exposed is mainly Quartzo-felspathic augen gneiss with thin bands of biotite schist belonging to Kharo Formation of Vaikrita Group. The general foliation of the exposed rock is $\mathrm{N30} 0^{\circ}-45^{\circ} \mathrm{W} / 20-25^{\circ}$ due $\mathrm{N}^{40}-65^{\circ} \mathrm{E}$. Besides foliation joint, two other prominent joint sets and some random joints have also been encountered.
\end{abstract}

The 5 to $20 \mathrm{~cm}$ thick shear seams have been encountered on the both the wall having persistence of more than $3 \mathrm{~m}$. The rock mass assessment of the rock ledge was carried out and it was found that most of the rock mass in the left wall falls in Class III i.e, 'Fair' category except from RD $\mathbf{8 5 - 9 2 m}$, where it is Class IV, whereas in the right wall it was found the rock mass falls in Class II to Class III, except from RD 110-113, 115-116, $119-122$, where it is in Class IV. In both walls logged, $85.2 \%$ of the rock mass falls in Class III, while $10.4 \%$ in Class IV \& $4.4 \%$ in Class II. The recommendations and suggestions were given in form of shotcrete and wiremesh as per rock class, low pressure grouting, three rows of rock bolting (the upper 2 rows are tension bolts and the lower row is of compression bolts) and to provide steel reinforcement in the base concrete in order to take care of any differential deformations due to varying rock conditions. Optical deformation monitoring system using $10 \mathrm{~m}$ long multipoint borehole extensometers on both the walls at $E L \pm 1830$ was also suggested to monitor deformations continuously.

Keywords-Satluj River; Tangling khad, Run off river; Kharo Formation; Vaikrita Group; RQD; EOT; rock ledge

\section{INTRODUCTION}

The Shongtong-Karcham Hydro-Electric Project is a run off the river scheme for harnessing hydropower potential of Satluj River between Powari and Ralli villages located in Kinnaur District of Himachal Pradesh[1]. The barrage site is located $1.5 \mathrm{~km}$ upstream of the confluence of Tangling Khad with Satluj River near Powari village. The diverted water shall be conveyed through an underground desilting chamber with $10.5 \mathrm{~m}$ finished diameter Head Race Tunnel for a distance of $8095.39 \mathrm{~m}$ long, $33 \mathrm{~m}$ diameter underground surge shaft and underground power house, to generate 450 MW ( $3 \times 150 \mathrm{MW})$ of hydro power and to let out the TRT in the $\mathrm{d} / \mathrm{s}$ at Ralli. The Project components are mostly placed in underground and are located on the left bank of the Satluj River.

\section{GENERAL GEOLOGY}

The project area exposed rocks belonging to Kharo formation of Vaikrita group comprising quartzo feldspathic gneisses, quartzite, high grade schist, migmatites. At barrage site Jutogh Group of rocks are exposed which consist of 


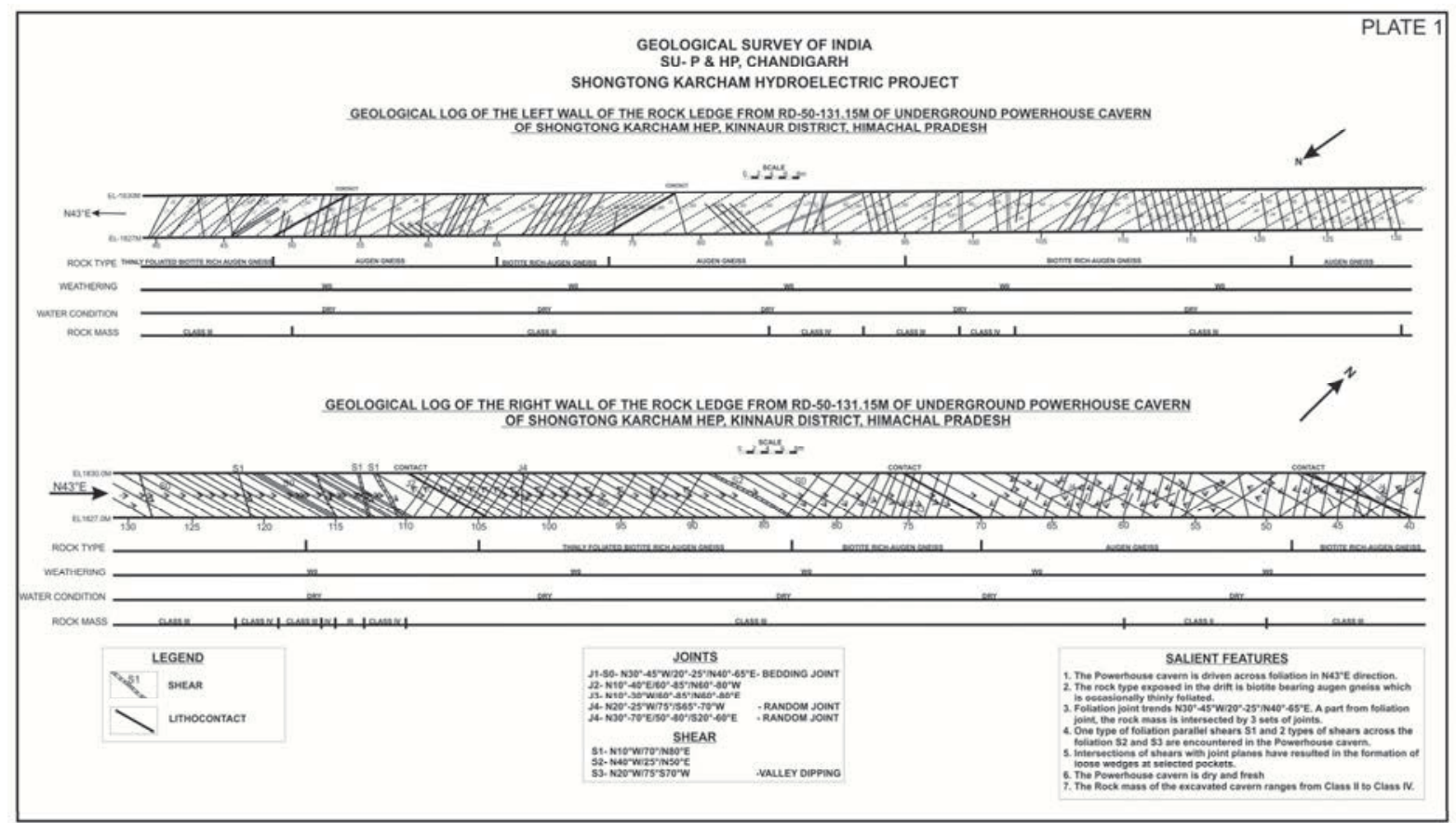

Fig. 1. Geological Log of the Left and Right walls of the Rock Ledges

garnetiferious mica schist, quartzite, massive and banded Psammatic gneiss with subordinate carbonaceous phyllites and carbonate bands, at places which have undergone polyphase metamorphism varying from green schist to amphibolite facies. The left abutment "Fig. 1" at the barrage site exhibits steep escarpment and biotite garnetiferious gneiss are exposed on scarp faces. The general trend of the strike is $\mathrm{N}-\mathrm{S} /$ dipping $30^{\circ}-40^{\circ}$ due east. Foliation is also parallel to the trend of strike ( $\mathrm{S} 1$ plane) and is traversed by three sets of joints.

\section{GEOTECHNICAL ASSESSMENT}

The subsurface power house $(131.15 \mathrm{~m}(\mathrm{~L}) \mathrm{x} 23 \mathrm{~m}(\mathrm{~W}) \mathrm{x}$ $44.29 \mathrm{~m}(\mathrm{H})$ has been excavated in $\mathrm{N} 43^{\circ} \mathrm{E}$ direction parallel to the principal stress axis. The detailed geological mapping of the rock ledge in the power house cavern "Fig. 2:", where Electrical Overhead Travelling (EOT) cranes is to be placed was carried out on 1:100 scale. The rock ledge has been excavated in $\mathrm{N} 43^{\circ} \mathrm{E}$ direction and is driven across the foliation plane. The $3 \mathrm{~m}$ height vertical wall of the rock ledge from base El. $\pm 1827 \mathrm{~m}$ to top $\mathrm{El} \pm 1830 \mathrm{~m}$ was excavated from RD 40m to RD 131.15m "Fig.2". During the geological mapping, it was found that the rock type mostly exposed is quartzo-felspathic augen gneiss[2], with thin bands of biotite schist. The general foliation of the exposed rock is $\mathrm{N} 30^{\circ}-45^{\circ} \mathrm{W} / 20-25^{\circ}$ due $\mathrm{N} 40-65^{\circ} \mathrm{E}$. Besides foliation joint, two other prominent joint sets and one random joint have also been observed.

\section{A. Left Wall}

The left wall comprises mostly of the quartzo-felspathic augen gneiss with occasional thinly foliated bands of biotite gneiss and schist "Fig. 2". On the left wall two sets of joints $\mathrm{J} 2$ and $\mathrm{J} 3$, other than foliation joints have been observed, beside one random joint $\mathrm{J} 4$. The $5-10 \mathrm{~cm}$ thick shear seam
TABLE I DETAILS OF JOINT AND SHEARS EXPOSED IN THE ROCK LEDGE OF THE POWERHOUSE CAVERN.

\begin{tabular}{|c|c|c|c|c|}
\hline $\begin{array}{l}\text { SI. } \\
\text { No }\end{array}$ & $\begin{array}{l}\text { Joint } \\
\text { Nos. }\end{array}$ & Azimuth & Characteristics & Remarks \\
\hline 1. & $\mathrm{~J} 1=\mathrm{S} 0$ & $\begin{array}{l}\mathrm{N} 30- \\
45^{\circ} \mathrm{W} / 20^{\circ} \\
-25^{0} \text { due } \\
\mathrm{N} 40-65^{\circ} \mathrm{E}\end{array}$ & $\begin{array}{lr}\text { Spacing } & 5-20 \mathrm{~cm}, \\
\text { opening } & 0.1-1 \mathrm{~cm}, \\
\text { persistence } & >6 \mathrm{~m}, \\
\text { smooth planar } & \end{array}$ & Bedding joint, \\
\hline 2. & $\mathrm{~J} 2$ & $\begin{array}{l}\text { N10- } \\
40^{\circ} \mathrm{E} / 60^{\circ}- \\
85^{\circ} \text { due } \\
\text { N60- } \\
80^{\circ} \mathrm{W}\end{array}$ & $\begin{array}{lr}\text { Spacing } & 50 \mathrm{~cm}-4 \mathrm{~m}, \\
\text { opening } & 0.1-3 \mathrm{~cm}, \\
\text { persistence } & >3 \mathrm{~m}, \\
\text { smooth planar }\end{array}$ & $\begin{array}{l}\text { Cutting across } \\
\text { the bedding } \\
\text { and forms } \\
\text { wedge with } \mathrm{J} 1\end{array}$ \\
\hline 3. & $\mathrm{~J} 3$ & $\begin{array}{l}\mathrm{N} 10- \\
35^{\circ} \mathrm{W} / 60^{\circ} \\
-85^{0} \text { due } \\
\mathrm{N} 60-80^{\circ} \mathrm{E}\end{array}$ & $\begin{array}{lr}\text { Spacing } & 10-20 \mathrm{~cm}, \\
\text { persistence } & 1-1.5 \mathrm{~m}, \\
\text { tight, } & \text { rough } \\
\text { undulating } & \end{array}$ & $\begin{array}{l}\text { Cutting } \\
\text { bedding plane } \\
\text { and forming } \\
\text { wedge with } \mathrm{J} 2 \\
\text { \& J4 }\end{array}$ \\
\hline 4. & $\mathrm{~J} 4$ & $\begin{array}{l}\mathrm{N} 20- \\
5^{\circ} \mathrm{W} / 75^{\circ} \\
\text { due } \\
\mathrm{S}^{\circ} 65^{\circ}- \\
70^{\circ} \mathrm{W}\end{array}$ & $\begin{array}{l}\text { Spacing } 5 \mathrm{~m}-10 \mathrm{~m} \text {, } \\
\text { tight, persistence }> \\
3 \mathrm{~m} \text {, rough undulating }\end{array}$ & $\begin{array}{l}\text { Random } \\
\text { joints. }\end{array}$ \\
\hline \multicolumn{5}{|c|}{ Shears } \\
\hline 1 & S1 & $\begin{array}{l}\mathrm{N} 10^{\circ} \mathrm{W} / 7 \\
0^{\circ} \\
\text { due } \\
\mathrm{N} 80^{\circ} \mathrm{E}\end{array}$ & $\begin{array}{l}10 \mathrm{~cm} \text { thick, effected } \\
\text { zone } 25 \mathrm{~cm} \text {, spacing } \\
3 \mathrm{~m}-12 \mathrm{~m} \text {, rock flour } \\
\text { filling, }\end{array}$ & $\begin{array}{l}\text { Valley } \\
\text { dipping }\end{array}$ \\
\hline 2 & S2 & $\begin{array}{l}\mathrm{N} 40^{\circ} \mathrm{W} / 2 \\
5^{\circ} \\
\text { due } \\
\mathrm{N} 50^{\circ} \mathrm{E}\end{array}$ & $\begin{array}{l}5-10 \mathrm{~cm} \text { thick, effected } \\
\text { zone } 10-20 \mathrm{~cm} \text {, bedding } \\
\text { parallel, persistence } \\
>3 \mathrm{~m} \text {, rock flour filling, }\end{array}$ & $\begin{array}{l}\text { Bedding } \\
\text { parallel }\end{array}$ \\
\hline 3 & S3 & $\begin{array}{l}\mathrm{N} 20^{\circ} \mathrm{W} / 7 \\
5^{\circ} \\
\text { due } \\
\mathrm{S} 70^{\circ} \mathrm{W}\end{array}$ & $\begin{array}{l}10-20 \mathrm{~cm} \text { thick, effected } \\
\text { zone- } 50 \mathrm{~cm} \text {, } \\
\text { persistence }>3 \mathrm{~m} \text {, rock } \\
\text { flour filling }\end{array}$ & $\begin{array}{l}\text { Valley } \\
\text { dipping }\end{array}$ \\
\hline
\end{tabular}

S2 along the foliation plane have been identified from RD $45 m-49 m$, RD $85 m-92 m$ while few shears seams S1 and S3 between RD $89 \mathrm{~m}$ to RD $105 \mathrm{~m}$ "Fig.3" have also been 


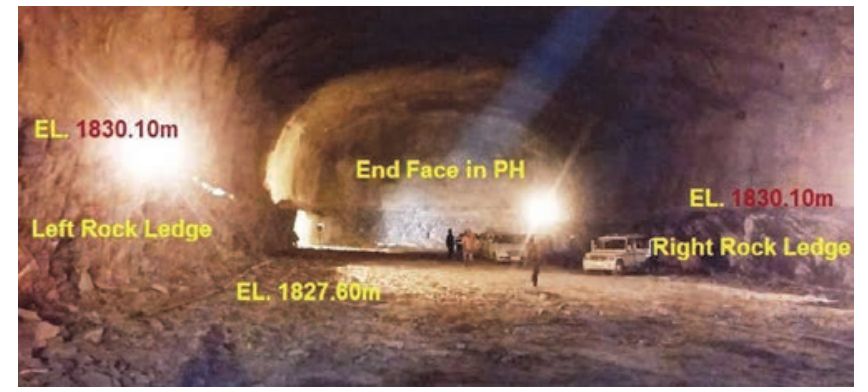

Fig.2. Powerhouse cavern showing the excavated rock ledge

delineated. The Shear S1 and S3 is valley dipping in upstream and downstream directions respectively. The details of various joints and shears encountered are as below in Table I.

The rock mass characterization of the left wall was made out and it was found that most of the rock mass falls in Class III and IV (Table II). The rocks are mostly fresh and dry.

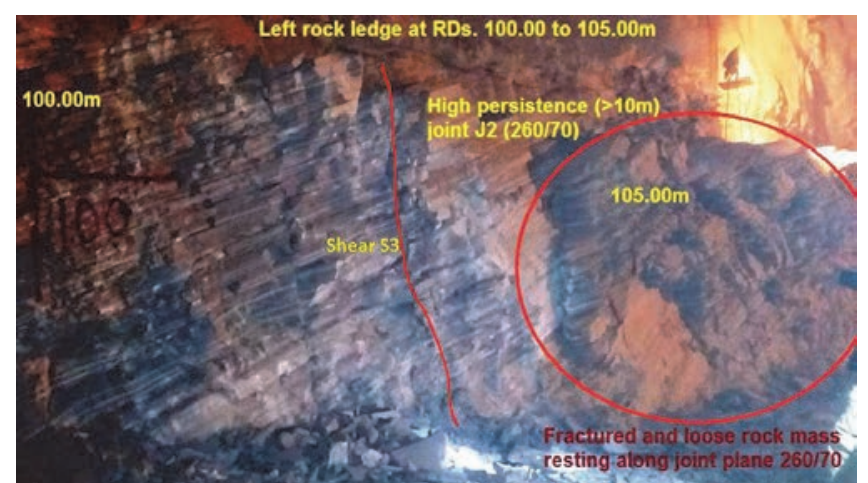

Fig.3.Shear S3 and the fractured poor strata exposed between RD 100-105 on the left wall of rock ledge of Powerhouse Cavern

TABLE II ROCK MASS ASSESSMENT OF THE LEFT WALL FROM RD-40-

\begin{tabular}{|l|l|l|}
\hline \multicolumn{3}{|c|}{$131.15 \mathrm{M}$} \\
\hline $40-50$ & Rock class & 'Q' Value \\
\hline $50-85$ & Class III & 4.66 \\
\hline $85-92$ & Class III & $5.3-6.3$ \\
\hline $92-99$ & Class IV & 1.0 \\
\hline $99-103$ & Class-III & 4.6 \\
\hline $103-131.15$ & Class-IV & 3.25 \\
\hline
\end{tabular}

\section{B. Right Wall}

The right wall also comprises mostly of the quartzofelspathic augen gneiss with occasional thinly foliated bands of biotite gneiss and schist[3]. On the right wall two sets of joints $\mathrm{J} 2$ and $\mathrm{J} 3$, other than foliation joints have been observed, beside that some random joints $\mathrm{J} 4$ are also present. On the right rock ledge wall, $2-15 \mathrm{~cm}$ thick shear seam S2 which is foliation parallel, have been delineated along the foliation plane from RD $83 \mathrm{~m}-88.6 \mathrm{~m}, 10-15 \mathrm{~cm}$ thick S1 shear has been encountered between RD110.5$112 \mathrm{~m}$ and RD 112.6m-113.5m "Fig.4" which are valley dipping in upstream direction.

The rock mass was calculated and mostly found to be in ranging from Class II to Class IV (Table III). The rocks are mostly fresh and dry.

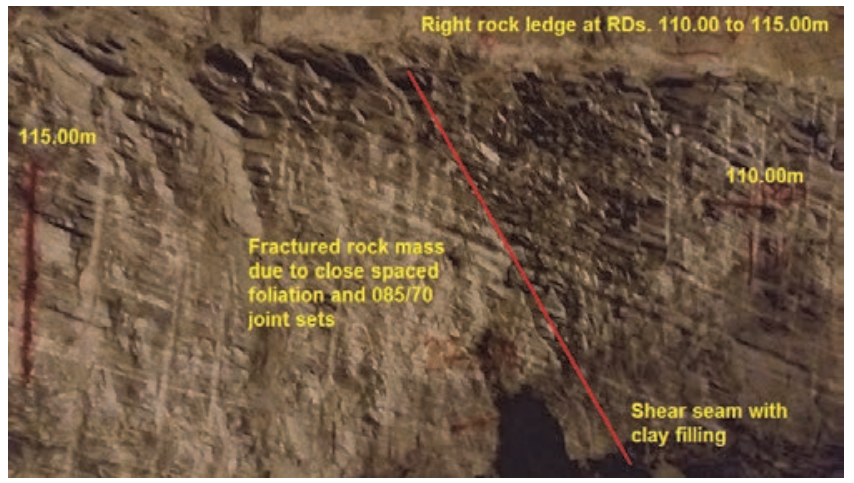

Fig.4. Shear S1 and the fractured poor strata due to close spaced foliation exposed between RD 110-115m on the right wall of rock ledge of Powerhouse Cavern

TABLE III ROCK MASS ASSESSMENT OF THE LEFT WALL FROM RD-40-

\begin{tabular}{|l|l|l|}
\hline RD & Rock class & 'Q' Value \\
\hline $40-50$ & Class III & $4.5-7.0$ \\
\hline $50-60$ & Class II & 10.1 \\
\hline $60-110$ & Class III & 6.6 \\
\hline $110-113$ & Class-IV & 1.0 \\
\hline $113-115$ & Class-III & 4.4 \\
\hline $115-116$ & Class-IV & 2.3 \\
\hline $116-119$ & Class-III & 4.1 \\
\hline $119-122$ & Class-IV & 3.0 \\
\hline $122-131.15$ & Class-III & 6.5 \\
\hline
\end{tabular}

\section{RECOMMENDATIONS}

Based on the geotechnical assessment and rock mass classification, following recommendations and suggestions were made:

1. It was suggested to manually remove the loose/blast damaged rock mass from the rock ledge and made up with suitable strength concrete.

2. To provide the shotcrete with wire mess as per the rock class.

3. Placing of levelling concrete above the undulating surface of rock ledge upto EL.1830.10m invert level of crane beam.

4. Low pressure grouting in the rock ledge vertically in downward direction from EL. $1830.10 \mathrm{~m}$ with grout hole spacing of $1 \mathrm{~m} \mathrm{c} / \mathrm{c}$ in one row at mid section upto a depth of $3.00 \mathrm{~m}$.

5. Rock bolts as per the rock mass classification to be provided.

6. Three rows of rock bolting (the upper 2 rows are tension bolts and the lower row is of compression bolts).

7. To provide 2 nd layer of shotcrete in consultation with design.To provide steel reinforcement in the base concrete in order to take care of any differential deformations due to varying rock conditions.

8. Optical deformation monitoring system using $10 \mathrm{~m}$ long multipoint borehole extensometers on both the walls at $\mathrm{EL} \pm 1830$ was also suggested to monitor deformations continuously. 


\section{ACKNOWLEDGMENT}

The authors extend their sincere thanks to Shri Sanjiv Kumar, Director Engineering Geology Division, State Unit: P.H. \& H.P., GSI, Chandigarh for his valuable suggestions during preparation of this paper. The investigations have been carried out under the overall guidance and supervision of Dr. K. Jayabalan, Director. The thanks are also owed to him. The last but not the least, the authors extend their sincere gratitude to Sri Ch. Venugopal Rao, Dy. D.G., GSI, SU: P \& HP, Chandigarh for his encouragement and administrative support to write the paper is gratefully acknowledged. The authors thankfully acknowledge S/Sri Ajay Patyal, General Manager, Virender Negi, Project Geologist Shongtong Karchham HEP, HPPCL for the logistic support provided during the geotechnical investigation at the project site.

\section{REFERENCES}

[1] Bhupender Singh, Report On "Detailed geological investigation of Shongtong - Karcham hydroelectric project, District - Kinnaur, Himachal Pradesh" Unpublished Report, Geol. Survey of India (FS.2012-13), 2013.

[2] V.V. Badareenarayana and R. Venugopala Rao, "Optimizing the use of in situ rock in underground powerhouses", IGC 2009, Guntur, India pp.217-220, 2009

[3] N.R. Barton, R, Lien, and J. Lunde, "Engineering classification of rock masses for the design of tunnel support", Rock Mech.6 (4), 189$239,1974$. 